\title{
Woolly aphids (Pemphigidae) on ornamental plants in container production
}

\author{
Mszyce z rodziny bawełnicowatych (Pemphigidae) \\ w pojemnikowej uprawie roślin ozdobnych
}

\author{
Gabriel Łabanowski, Grażyna Soika, Edyta Kowalska
}

\section{Summary}

The following species of woolly aphids appeared in containers with coniferous shrubs: Gootiella tremulae on yews (Juniperus chinensis, J. horizontalis, J. $\times$ media and J. squamata), Prociphilus (Stagona) pini on pines (Pinus sylvestris and P. mugo) and Pachypappa vesicalis on Norway spruce (Picea abies). In container production of perennial plants, Colopha compressa was feeding on roots of sedges (Carex buchananii and C. morowii) and Thecabius (Parathecabius) lysimachiae on roots of golden creeping jenny (Lysimachia nummularia). In containers with deciduous shrubs such as Thunberg's barberry (Berberis thunbergii), smooth hydrangea (Hydrangea arborescens), weigela (Weigela florida), shrubby cinquefoil (Potentilla fruticosa), Japanese spiraea (Spiraea japonica) and Grefsheim spiraea (Spiraea $\times$ cinerea), the lettuce root aphid (Pemphigus bursarius) was found. However, this aphid was not inhibiting roots of deciduous shrubs, but was feeding on roots of common dandelion (Taraxum officinale) - common weed in container production.

Key words: wooly aphids, ornamental shrubs, containers, nurseries

\section{Streszczenie}

W uprawie pojemnikowej krzewów iglastych występują: na jałowcach (Juniperus chinensis, J. horizontalis, J. $\times$ media i J. squamata) bawełnica osikowo-jałowcowa (Gootiella tremulae), na sosnach (Pinus sylvestris i P. mugo) bawełnica głogowo-sosnowa [Prociphilus (Stagona) pini], na świerkach (Picea abies) bawełnica topolowo-świerkowa (Pachypappa vesicalis). W pojemnikowej uprawie bylin, na korzeniach turzyc (Carex buchananii i C. morowii) żeruje bawełnica wiązowo-turzycowa (Colopha compressa), a na korzeniach tojeści rozesłanej (Lysimachia nummularia) odmiana Aurea bawełnica topolowo-tojeściowa [Thecabius (Parathecabius) lysimachiae]. W pojemnikach z krzewami liściastymi: berberys Thunberga (Berberis thunbergii), hortensja krzewiasta (Hydrangea arborescens), krzewuszka cudowna (Weigela florida), pięciornik krzewiasty (Potentilla fruticosa), tawuła japońska (Spiraea japonica) i tawuła szara (Spiraea $\times$ cinerea) stwierdzono bawełnicę topolowo-sałatową - Pemphigus bursarius. Mszyca ta zasiedlała nie korzenie krzewów liściastych, lecz korzenie chwastu - mniszka lekarskiego (Taraxum officinale).

Słowa kluczowe: bawełnice, krzewy ozdobne, pojemniki, szkółki 


\section{Wstęp / Introduction}

W Polsce mszyce z rodziny bawełnicowatych (Pemphigidae) notowano przede wszystkim na żywicielach pierwotnych - topolach i wiązach, na liściach których tworzą różnego rodzaju wyrośla (Krzywiec 1978; Barczak 1987, 2004; Hałaj 1999; Wrzesińska i Wawrzyniak 2008). W Polsce badania nad mszycami korzeniowymi warzyw prowadzili Cichocka i Goszczyński (1978, 1992), Goszczyński i Cichocka (1986) oraz Łuczak (2009). Na korzeniach roślinach iglastych, jako żywicielach wtórnych uprawianych w pojemnikach w szkółkach, bawełnice obserwowano po raz pierwszy w latach 1998-2001. Na korzeniach jałowców (Juniperus chinensis, J. communis, J. glauca, J. scopulorum, J. virginiana) kolonie tworzyła bawełnica osikowo-jałowcowa - Gootiella tremulae Tullgren, 1925, na korzeniach sosen (Pinus sylvestris, P. mugo) obserwowano kolonie bawełnicy głogowososnowej - Stagona pini (Burmeister, 1835), a na korzeniach świerków (Picea abies, $P$. glauca) notowano kolonie bawełnicy osikowo-świerkowej - Pachypappa vesicalis (Koch, 1856). Ponadto na korzeniach bylin rosnących w pojemnikach obserwowano Parathecabius lysimachiae na Lysymachia nummularia odmiana Aurea i Thecabius affinis na Ranunculus aceris odmiana Multiplex (Łabanowski i Soika 2001).

Celem pracy były dalsze obserwacje nad występowaniem mszyc korzeniowych w pojemnikowej produkcji krzewów ozdobnych ze szczególnym uwzględnieniem krzewów liściastych.

\section{Materiały i metody / Materials and methods}

Obserwacje nad występowaniem mszyc korzeniowych w szkółkach produkujących krzewy ozdobne prowadzono w latach 2001-2012, w województwach: kujawskopomorskim (Stary Dwór koło Bydgoszczy), lubelskim (Sielce koło Puław), łódzkim (Nowy Dwór koło Skierniewic) i śląskim (Zaborze koło Oświęcimia). W każdej szkółce przeglądano korzenie 30 krzewów liściastych jednego gatunku rośliny, a po wykryciu pojemników z mszycami przewożono je do laboratorium w celu przygotowania preparatów mikroskopowych. W tekście oznaczono skrótami: Dz - bezskrzydłe dzieworódki, U uskrzydlone dzieworódki, N - nimfy i L - larwy. Bawełnice oglądano pod mikroskopem świetlnym przy powiększeniu $40 \times$ i po wykonaniu zdjęć oznaczano do gatunku na podstawie kluczy Heie (1980) oraz Blackman i Eastop (1994). Nazewnictwo łacińskie podano według opracowania Węgierka i Wojciechowskiego (2004), a nazewnictwo polskie za Nawrotem (2008).

\section{Wyniki i dyskusja / Results and discussion}

Wszystkie obserwowane gatunki bawełnic (Pemphigidae) z wyjątkiem Colopha compressa (Eriosomatinae) należą do podrodziny Pemphiginae, dla których żywicielem pierwotnym są topole, wiązy i głogi, a żywicielem wtórnym krzewy iglaste (jałowiec, sosna, świerk) lub zielne (tojeść, turzyca), na których zimują osobniki pokolenia anholocyklicznego.

Colopha compressa (Koch 1856) - bawełnica wiązowoturzycowa $=$ kogutnica wiązowa

Zebrany materiał: z korzeni Carex buchananii (Zaborze koło Oświęcimia 22.07.2011 - Dz; Sielce koło Puław 16.09.2011 - Dz, N i L), z korzeni C. morowii odmiana Variegata (Zaborze koło Oświęcimia 22.07.2011 - Dz i L; Sielce koło Puław 16.09.2011 - Dz, N i L). Mszyca ta była obserwowana $\mathrm{w}$ Bydgoszczy na wiązie polnym (Ulmus minor) w niewielkim nasileniu (Wrzesińska i Wawrzyniak 2008), a w parkach Lublina na wiązie polnym i wiąie górskim (U. glabra) w ogóle nie występowała (Kmieć i Kot 2010).

Cechy diagnostyczne (rys. 1): bezskrzydłe dzieworódki (zebrane pod koniec lipca były wypełnione larwami) nogi ciemne, stopa 1-członowa. Oczy trójfasetkowe. Czułki 4-członowe, rynaria pierwotne na III i IV członie otoczone krótkimi włoskami. Płytki gruczołów woskowych bardzo małe składaja się $\mathrm{z}$ jednej fasetki środkowej otoczonej 6-12 fasetkami trójkątnymi lub owalnymi, rozmieszczone są na głowie, tułowiu i odwłoku. Nimfy (zebrane w połowie września) całkowicie jasne

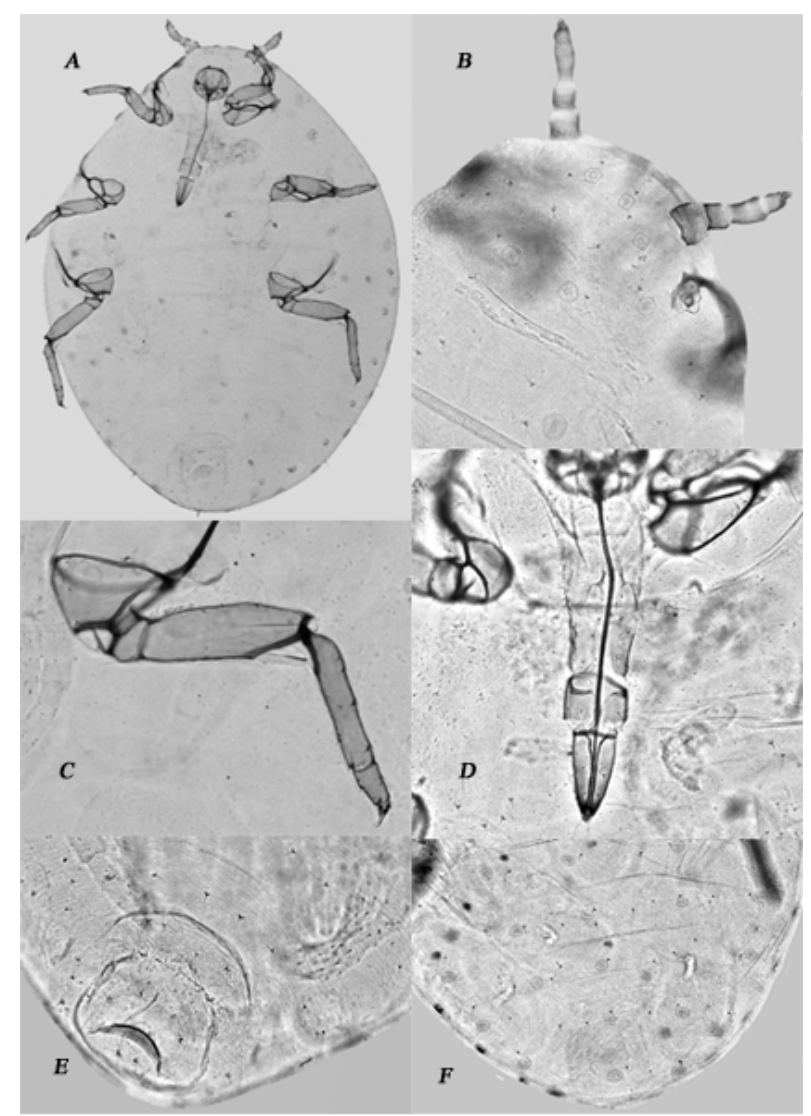

Rys. 1. C. compressa: A - samica, B - głowa i czułki, C - noga, D - kłujka, E - tarcza analna i genitalna, F - płytki gruczołów woskowych

Fig. 1. C. compressa: A - female, B - head and antennae, C leg, D - rostrum, E - anal and genital plates, F - wax gland plates 
z zaczątkami skrzydeł, oczy złożone barwy czerwonej, czułki 6-członowe, rynarium pierwotne otoczone włoskami na ostatnim członie. Płytki gruczołów woskowych rozmieszczone na głowie, tułowiu i odwłoku. Larwy (zebrane w połowie września) - czułki 4-członowe. Oczy trójfasetkowe. Podobnie, jak u nimf na całym ciele rozmieszczone płytki gruczołów woskowych.

Gootiella tremulae Tullgren 1925 - bawełnica osikowojałowcowa

Zebrany materiał: $\mathrm{z}$ korzeni J. squamata odmiana Blue Star (Nowy Dwór koło Skierniewic 23.03.2005 - Dz), korzenie Juniperus $\times$ media odmiana Mint Julep (Nowy Dwór koło Skierniewic 23.03.2005 - Dz; 4.05.2006 - Dz, 11.05.2006 - Dz, 8.06.2006 - Dz), J. chinensis odmiana Spartan (Nowy Dwór koło Skierniewic 4.05.2006 - Dz; 8.06.2006 - Dz; Piaseczno koło Warszawy 16.06.2006 Dz), J. horizontalis odmiana Hughes (Nowy Dwór koło Skierniewic 4.05.2006 - Dz; 11.05.2006 - L; 28.06.2006 Dz, N i L). Żywicielem pierwotnym tej mszycy jest osika (Populus tremula), na której żeruje wewnątrz złożonego połówkami do siebie liścia, a żywicielem wtórnym są różne gatunki jałowców, a nie jak podaje Heie (1980) tylko jałowiec pospolity (J. communis). Na korzeniach jałowców mszyca zimuje, a wiosną żeruje i rozmnaża się aż do końca czerwca lub dłużej.

Cechy diagnostyczne (rys. 2): dzieworódki bezskrzydłe (zebrane w maju i na początku czerwca; od początku maja

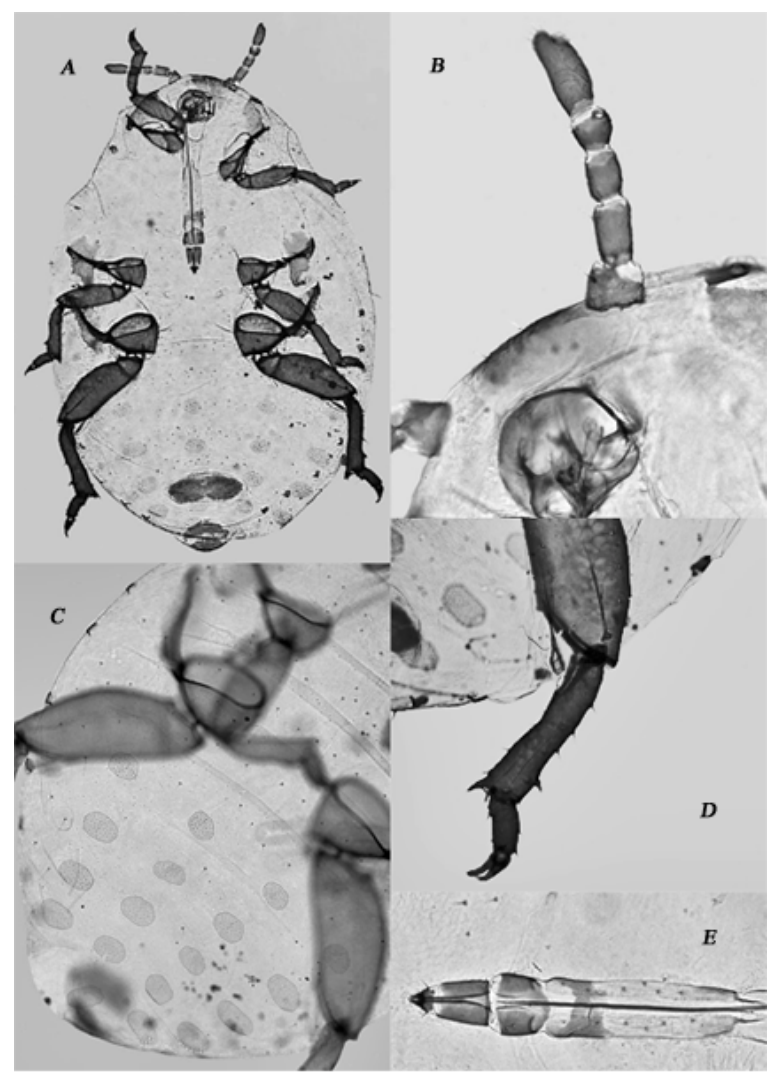

Rys. 2. G. tremulae: A - samica, B - czułek, C - płytki gruczołów woskowych, D - noga, E - kłujka

Fig. 2. G. tremulae: $\mathrm{A}-$ female, $\mathrm{B}-$ antennae, $\mathrm{C}-$ wax gland plates, D - leg, E - rostrum zbierano samice wypełnione larwami) - czułki 5-członowe, człon III czułka dłuższy od członu IV, a krótszy od członu V. Oczy trójfasetkowe, kłujka z jasną strefą subapikalną, sięga do bioder tylnych nóg. Nogi całe ciemne, golenie tylnych nóg silnie pogrubione, włoski na II członie stopy tylnej krótsze niż kolce na goleni. Płytki gruczołów woskowych ułożone w 5 rzędach, przy czym w pierwszych 4 rzędach po 4 płytki, a w ostatnim rzędzie tylko 2 płytki; płytka składa się z licznych rurek i posiada jeden długi włosek. Larwy (zebrane w połowie maja) podobne są do dzieworódek, ale mniejsze i bez wykształconej tarczy genitalnej. Nimfy (zebrane pod koniec czerwca) mają zaczątki skrzydeł, czułki są 6-członowe, przy czym człon III jest dłuższy od członu IV i V, a podobnej długości co człon VI. Oczy złożone, kłujka sięga pomiędzy I a II parę nóg. Tarcza genitalna i tarcza analna wykształcone.

Pemphigus (Pemphigus) bursarius (Linnaeus 1758) bawełnica topolowo-sałatowa

Zebrany materiał: $\mathrm{z}$ korzeni Taraxum officinale w pojemnikach z Berberis thunbergii (Stary Dwór koło Bydgoszczy 26.05.2012 - nimfy; 29.06.2012 - L, Dz; 15.09.2012 - L, N, U; 12.10.2012 - L, N), Hydrangea macrophylla (Koronowo koło Bydgoszczy 28.07.2011 - Dz i L), Euonymus fortunei odmiana Coloratus (Zaborze koło Oświęcimia 20.07.2011 Dz), Weigela florida (Nowy Dwór koło Skierniewic 27.07. i 10.08.2006 - Dz), Potentilla fruticosa (Nowy Dwór koło Skierniewic 4.05.2006 - Dz i L; 21.05.2006 - Dz; 8.06.2006 - Dz; 16.06.2006 - L; 28.06.2006 - Dz; 27.07.2006 - Dz i L; 10.08.2006 - L.), Spiraea japonica odmiana Gold Flame (Nowy Dwór koło Skierniewic 16.03.2006 - Dz; 11.05.2006 - Dz i L; 27.07.2006 - L), odmiana Anthony Waterer (Nowy Dwór koło Skierniewic 16.03.2006 - Dz, 22.05.2006 - L; 8.06.2006 - Dz i L; 10.08.2006 - Dz), Spiraea $\times$ cinerea odmiana Grefsheim (Nowy Dwór koło Skierniewic 22.06.2004 - L; 4.05.2006 - Dz i L; 8.06.2006 - Dz). Jest to gatunek dwudomny, dla którego żywicielem pierwotnym jest topola czarna, na której ogonkach liściowych tworzy buławkowate wyrośla. W Polsce występuje powszechnie na żywicielu wtórnym - sałacie i stąd znana jest jako jej szkodnik żerujący na korzeniach (Cichocka i Goszczyński 1978). Miller i wsp. (2005) wykazali preferencje pokarmowe bawełnicy topolowo-sałatowej $\mathrm{W}$ stosunku do dziko rosnących roślin $\mathrm{z}$ rodziny Asteraceae.

Cechy diagnostyczne (rys. 3): dzieworódki bezskrzydłe (zebrane na początku maja) - czułki i nogi ciemne. Oczy trójfasetkowe. Płytki gruczołów woskowych w 3 lub w 4 rzędach po 4 płytki (segmenty odwłoka III-VI lub V-VI) i 2 płytki gruczołowe na VII segmencie. Czułki 5-członowe, człon V tak długi, jak człony II i III; wyrostek końcowy $0,25 \times$ podstawa ostatniego członu. Kłujka z jasną strefą subapikalną, człon końcowy kłujki około $0,8 \times$ długość II członu stopy tylnej. Nimfy (zebrane w połowie września były wypełnione larwami) jasne z ciemnymi czułkami i nogami oraz zaczątkami skrzydeł. Oczy złożone, czerwone. Czułki 6-członowe, na V i VI członie znajduje się rynarium pierwotne otoczone rzęskami. Na odwłoku rozmieszczone płytki gruczołów woskowych. 


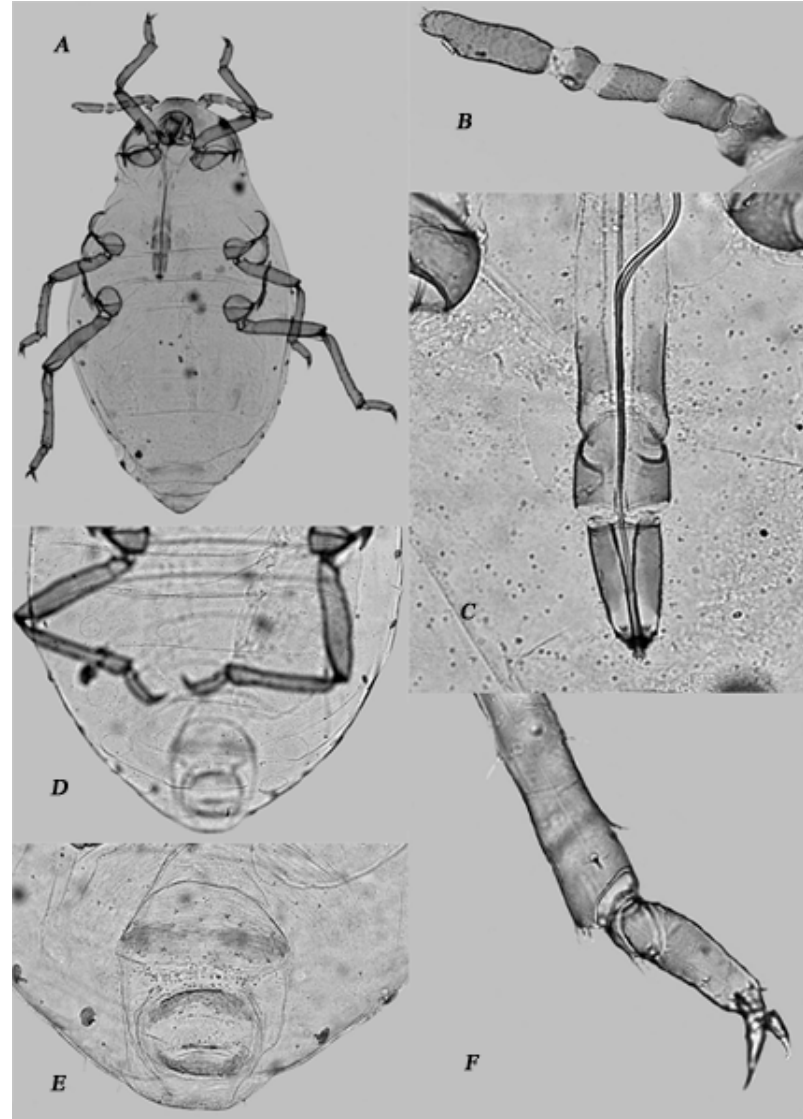

Rys. 3. P. bursarius: A - samica, B - czułek, C - kłujka, D - płytki gruczołów woskowych, E - tarcza analna, F - noga,

Fig. 3. P. bursarius: A - female, $\mathrm{B}-$ antenna, $\mathrm{C}-$ rostrum, $\mathrm{D}$ - wax gland plates, $\mathrm{E}$ - anal plate, $\mathrm{F}$ - leg

Pachypappa vesicalis Koch 1856 - bawełnica topolowoświerkowa

Zebrany materiał: z korzeni Picea abies (Nowy Dwór koło Skierniewic 26.04.2012 - Dz), P. abies odmiana Nidiformis (Bielsko Biała 15.11.2011 - Dz). W Polsce mszyca ta była obserwowana wcześniej na korzeniach świerka pospolitego odmiana Nidiformis i Procumbens, a także na korzeniach świerka białego ( $P$. glauca) odmiana Conica w szkółkach pojemnikowych (Łabanowski i Soika 2001). Klucz do morf dwóch gatunków mszyc $-P$. vesicalis i P. lactea opracował Carter i Danielsson (1991).

Cechy diagnostyczne (rys. 4): dzieworódki bezskrzydłe (zebrane po połowie maja były wypełnione larwami). Czułki i nogi brązowe. Oczy trójfasetkowe. Czułki 5-członowe, człon III dłuższy od członu II i IV oraz nieco krótszy niż człon $\mathrm{V}$. Na członach IV i $\mathrm{V}$ umieszczone są rynaria pierwotne otoczone rzęskami. Kłujka sięga do bioder III pary nóg, końcowy człon kłujki z jasną strefą subapikalną. Płytki gruczołów woskowych ułożone w 4 rzędach po 4 płytki (segmenty III-VI) i na segmencie VII - 2 płytki. Płytki składają się z rurek i umieszczony jest jeden włosek. Tarcza genitalna $\mathrm{z}$ ponad 10 włoskami. Tarcza analna z mniej niż 10 włoskami.

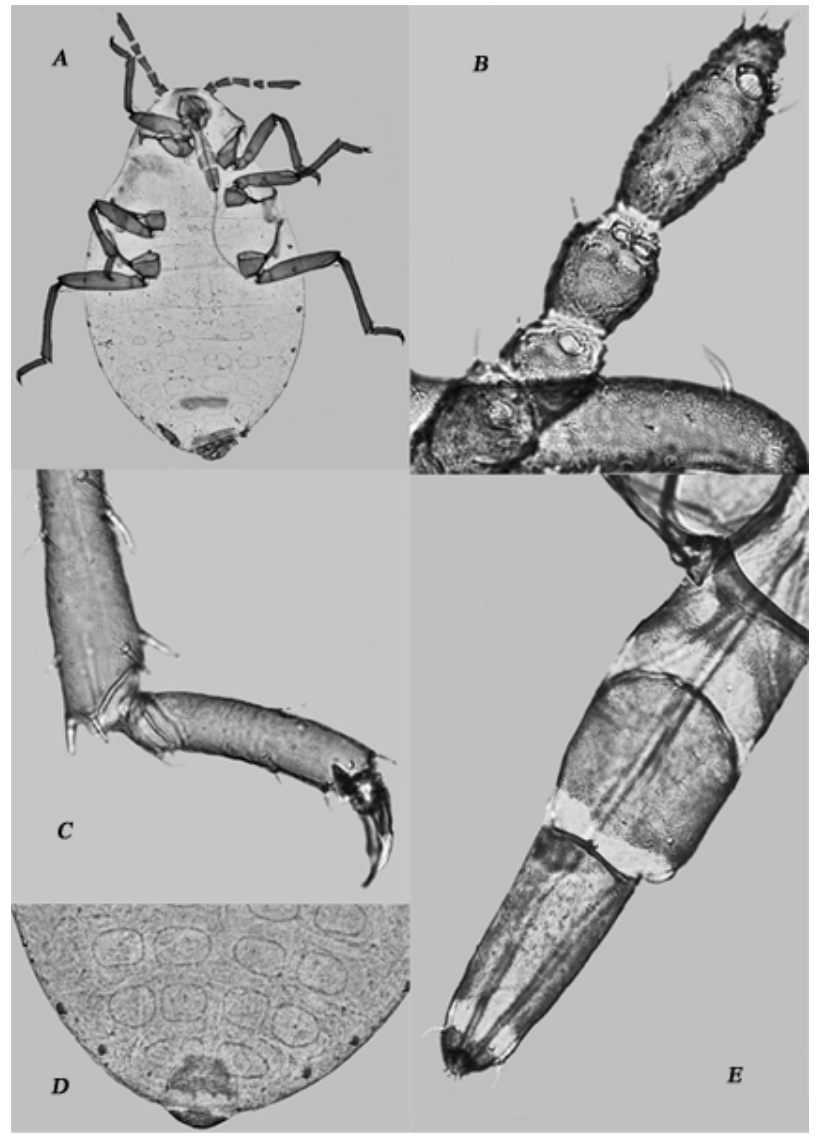

Rys. 4. P. vesicalis: A - samica, B - czułek, C - noga, D - płytki gruczołów woskowych, E - kłujka

Fig. 4. P. vesicalis: A - female, B - antenna, C - leg, D - wax gland plates, $\mathrm{E}$ - rostrum

Prociphilus (Stagona) pini (Burmeister 1835) - bawełnica głogowo-sosnowa

Zebrany materiał: z korzeni Pinus sylvestris (Częstochowa 18.06.2001 - Dz i L), P. mugo var. pumilio (Nowy Dwór 22.05.2006 - Dz). W Polsce mszyca ta była notowana, szczególnie licznie na korzeniach siewek sosny pospolitej, rzadziej na korzeniach sosny kosodrzewiny ( $P$. mugo) w szkółkach pojemnikowych (Łabanowski i Soika 2001). Mszycę tę w Szwecji na korzeniach $P$. mugo rosnącej w pojemnikach obserwował także Pettersson (1978), a w Belgii podejmowano nawet próbę jej zwalczania (Heungens i Buysse 1998).

Cechy diagnostyczne (rys. 5): dzieworódki bezskrzydłe (zebrane $\mathrm{w}$ drugiej połowie maja były wypełnione larwami) - płytki gruczołów woskowych słabo lub wcale niewidoczne. Czułki i nogi brązowe. Oczy trójfasetkowe. Człon wierzchołkowy kłujki bez jasnej strefy subapikalnej, tej samej długości co II człon stopy nogi tylnej. Czułki 5-członowe, sięgają pomiędzy I a II parę nóg, człon III dłuższy od członu II i wyraźnie dłuższy od członu IV, ale tylko nieco krótszy od członu $\mathrm{V}$, wyrostek końcowy czułka $0,33 \times$ długość podstawy $\mathrm{V}$ członu. 


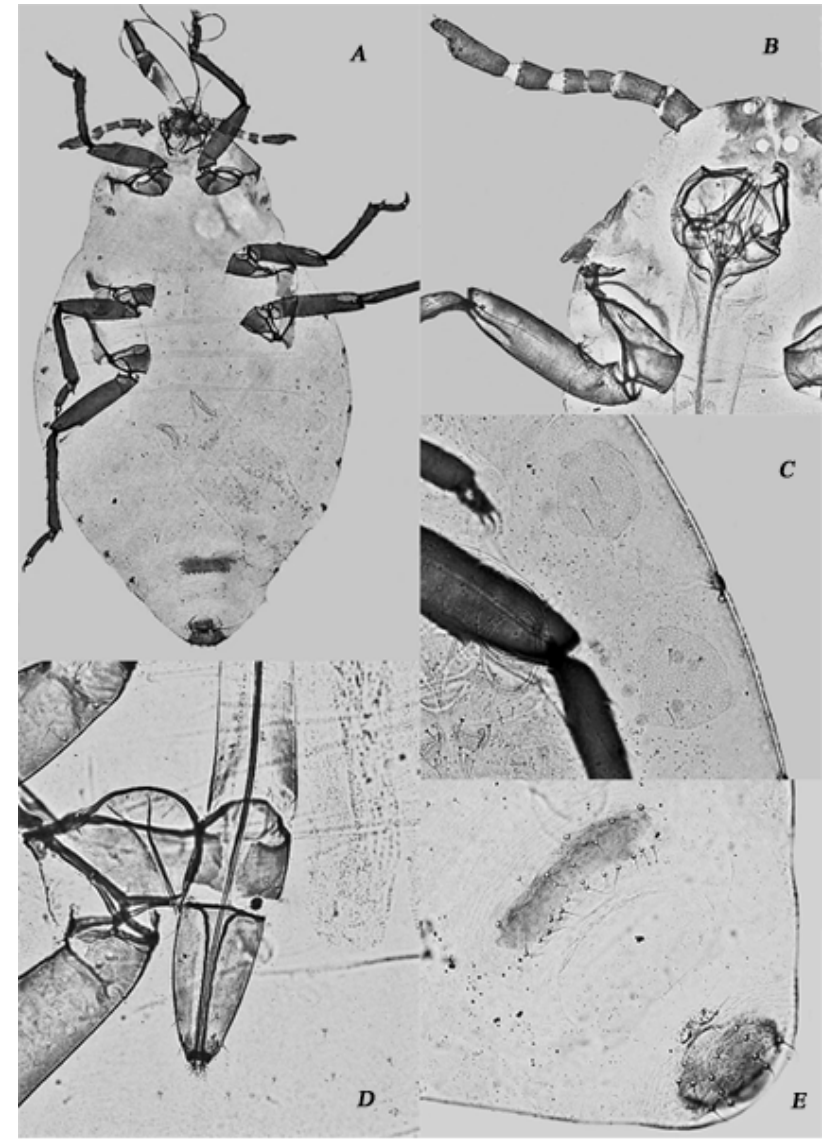

Rys. 5. P. pini: A - samica, B - głowa i czułek, C - pleuryty, D - kłujka, D - płytka analna i genitalna

Fig. 5. P. pini: A - female, $\mathrm{B}-$ head and antenna, $\mathrm{C}-$ pleurites, $\mathrm{D}$ - rostrum, $\mathrm{E}$ - anal and genital plates

Thecabius (Parathecabius) lysimachiae Börner 1916 bawełnica topolowo-tojeściowa

Zebrany materiał: z korzeni Lysymachia nummularia odmiana Aurea (Nowy Dwór koło Skierniewic 14.04.2008 - L); Rawka koło Skierniewic 22.09.2006 - Dz). Mszyca ta występuje powszechnie w pojemnikowej uprawie tojeści rozesłanej odmiana Aurea na terenie całego kraju (Soika i Łabanowski 2003).

Cechy diagnostyczne (rys. 6): dzieworódki bezskrzydłe (zebrane w drugiej połowie września były z larwami wewnątrz ciała) - czułki i nogi brązowe. Płytki gruczołów woskowych słabo widoczne w 5 rzędach po 4 płytki w rzędzie (na III-VI segmencie odwłoka) i 2 płytki na VII segmencie. Oczy trójfasetkowe. Czułki 5-członowe (połączony człon III z IV) lub 6-członowe, przy czym człon VI dłuższy od członów IV i V razem, wyrostek końcowy $0,33 \times$ podstawa ostatniego członu czułka. Kłujka bez jasnej strefy subapikalnej, sięga do bioder III pary nóg, człon końcowy kłujki $0,75 \times$ długość II członu stopy tylnej nogi.

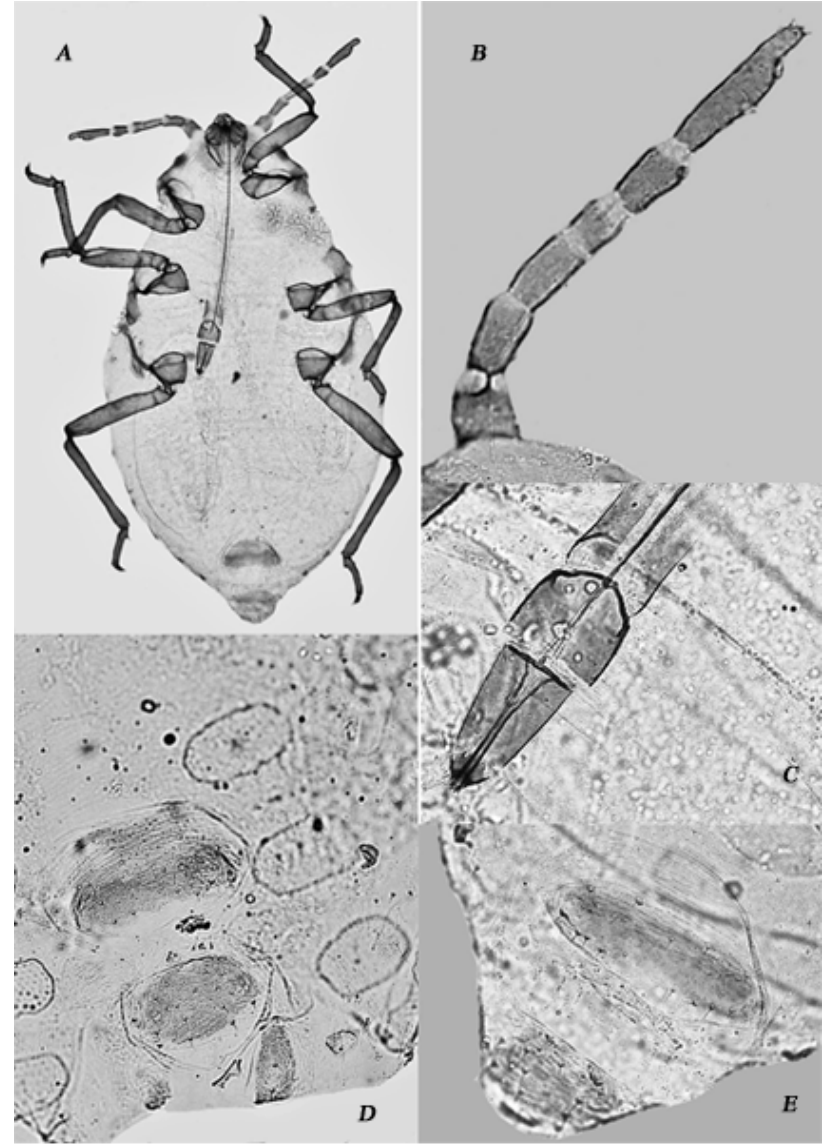

Rys. 6. T. lysimachiae: A - samica, B - czułek, C - kłujka, D - płytki gruczołów woskowych, E - tarcza analna i genitalna

Fig. 6. T. lysimachiae: A - female, B - antenna, C - rostrum, $\mathrm{D}$ - wax gland plates, $\mathrm{E}-$ anal and genital plates

\section{Wnioski / Conclusions}

1. Korzenie turzyc (Carrex spp.) uprawianych w pojemnikach zasiedla bawełnica wiązowo-turzycowa - C. compressa.

2. W pojemnikach na korzeniach sosen występuje bawełica głogowo-sosnowa - P. (Stagona) pini, zaś na korzeniach świerków bawełnica topolowo-świerkowa $P$. vesicalis, a na korzeniach jałowców bawełnica osikowo-jałowcowa-G. tremulae.

3. Na korzeniach tojeści rozesłanej uprawianej w pojemnikach występuje bawełnica topolowo-tojeściowa - T. (Parathecabius) lysimachiae.

4. W pojemnikach $\mathrm{z}$ krzewami liściastymi występuje bawełnica topolowo-sałatowa $-P$. bursarius, która żeruje na korzeniach chwastu - mniszka lekarskiego (Taraxacum officinale), a nie na korzeniach krzewów ozdobnych uprawianych w pojemnikach.

\section{Literatura / References}

Barczak T. 1987. Stan badań nad podrodziną Pemphiginae (Homoptera, Aphidoidea, Pemphigidae) w Polsce. Wiad. Entomol. 7 (1-2): $27-37$. 
Barczak T. 2004. Niektóre aspekty bionomii i ekologii mszycy przerostek skrętnik, Pemphigus spirothecae Pass. (Homoptera: Pemphigidae) w środowisku miejskim. s. 235-255. W: „Fauna miast Europy Środkowej 21 wieku” (P. Indykiewicz, T. Barczak, red.). Wyd. LOGO, Bydgoszcz, 584 ss.

Blackman R.L., Eastop V.F. 1994. Aphids on the World's Tress. An Identification and Information Guide. CAB International \& The Natural History Museum, London, 987 pp.

Carter C.I., Danielsson R. 1991. Two spruce root aphids, Pachypappa vesicalis and Pachypappa lactea new to Britain with illustrated keys to the morphs from Picea roots. Entomologist 110 (2): 66-74.

Cichocka E., Goszczyński W. 1978. O dwóch gatunkach mszyc - nowych szkodnikach sałaty w Polsce. Zesz. Probl. Post. Nauk Rol. 208: $127-130$.

Cichocka E., Goszczyński W. 1992. Root aphids on cultivated plants in Poland. Aphids and Other Homopterous Insects. 3: 3-12, 115 pp.

Goszczyński W., Cichocka E. 1986. Szkodliwość mszyc żerujących na korzeniach marchwi. Zesz. Probl. Post. Nauk Rol. 329: 541-544.

Hałaj R. 1999. Eriososma (Schizoneura) anncharlotteae Danielson, 1979 (Homoptera, Aphidinea: Pemphigidae: Eriosomatinae) - nowy gatunek w Polsce, z kluczem do oznaczania krajowych gatunków mszyc z podrodziny Eriostomatinae na podstawie wyrośli na wiązach (Ulmus spp.). Acta Ent. Siles. 5-6: 33-39.

Heie O.E. 1980. The Aphidoidea (Hemiptera) of Fennoscandia and Denmark. I. General Part. The Families Mindaridae, Hormaphididae, Thelaxidae, Anoeciidae and Pemphigidae. Scand. Science Press Ltd. Klampenborg, Denmark 9, 236 pp.

Heungens A., Buysse G. 1998. Control of the pine root aphid Stagona pini on container grown pine shrubs Pinus mugo by irrigation with insecticides solutions. Meded.-Facult. Landbouw. Toegep. Biolog. Wertensch. Univ. Gent 63 (2b): 581-584.

Kmieć K., Kot I. 2010. Występowanie mszyc z podrodziny Eriosomatinae na wiązach w parkach Lublina. Ann. UMCS Lublin - Polonia 29 (1): 7-13.

Krzywiec D. 1978. Bawełnica północna - potencjalny szkodnik topoli berlińskiej w Polsce. Zesz. Probl. Post. Nauk Rol. 208: 131-135.

Łabanowski G., Soika G. 2001. Aphids of the Pemphigidae family living on roots of ornamental plants in Poland. Aphids ond other Homopterous Insects 8: 175-183, $439 \mathrm{pp}$.

Łuczak I. 2009. Występowanie mszyc korzeniowych na odmianach marchwi. [Occurrence of root aphids on carrot cultivars]. Prog. Plant Prot./Post. Ochr. Roślin 49 (3): 1195-1198.

Miller N.J., Kift N.B., Tatchell G.M. 2005. Host-associated populations in the lettuce root aphid, Pemphigus bursarius (L.). Heredity 94: $556-564$.

Nawrot J. 2008. Leksykon owadów. Inst. Ochr. Roślin - PIB, Poznań, 551 ss.

Pettersson M.L. 1978. Aphids, Prociphilus pini (Koch 1858), on the roots of potted mountain pine (Pinus mugo). Vaextskyddsnotiser 42 (6): 85-86.

Soika G., Łabanowski G., Brzozowska-Michalak J. 2003. Occurrence of phytophagous mites and insects on perennials in Botanical gardens and urban areas in Poland. p. 24-35. In: „Protection of Plant Collections against Pests and Diseases”. Vol. 2 (K. Wiech, B. Zemanek, eds.). Uniwersytet Jagielloński, Akademia Rolnicza, Kraków, 141 pp.

Węgierek P., Wojciechowski W. 2004. Mszyce (Aphidoidea). s. 254-266. W: „Fauna Polski - Charakterystyka i wykaz gatunków”. T. 1 (W. Bogdanowicz, E. Chudzicka, I. Pilipiuk, E. Skibińska, red.). Muzeum i Instytut Zoologii PAN, Warszawa, 509 ss.

Wrzesińska D., Wawrzyniak M. 2008. Bawełnice (Aphidinea) zasiedlające wiąz polny Ulmus minor na terenie Bydgoszczy. s. $405-408$. W: „Fauna miast. Ochronić różnorodność biotyczną w miastach” (P. Indykiewicz, L. Jerzak, T. Barczak, red.). SAR Pomorze, 634 ss. 